\title{
Oppblåst mage uten gass
}

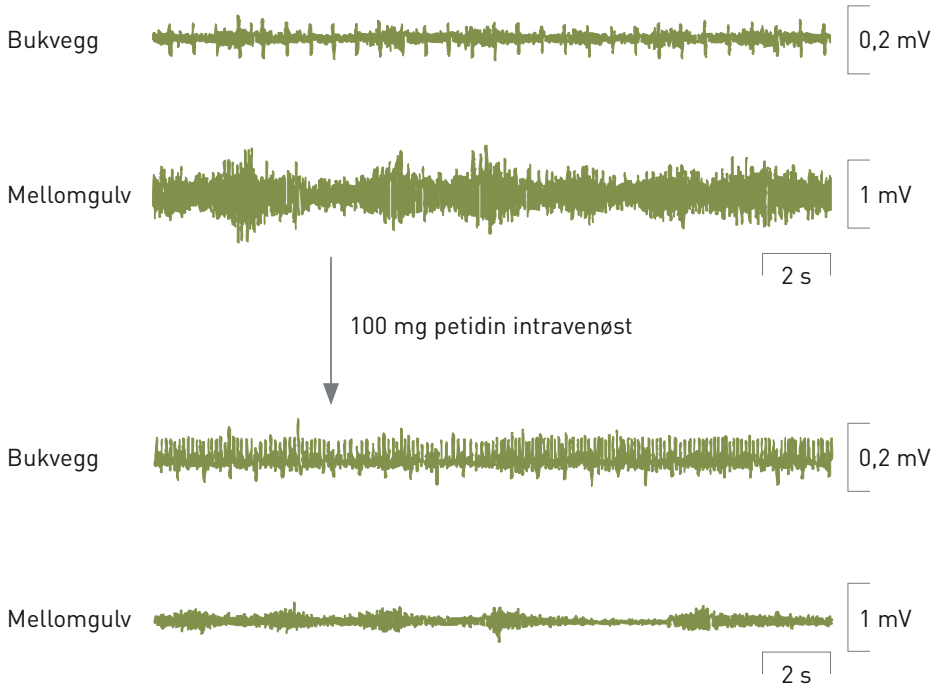

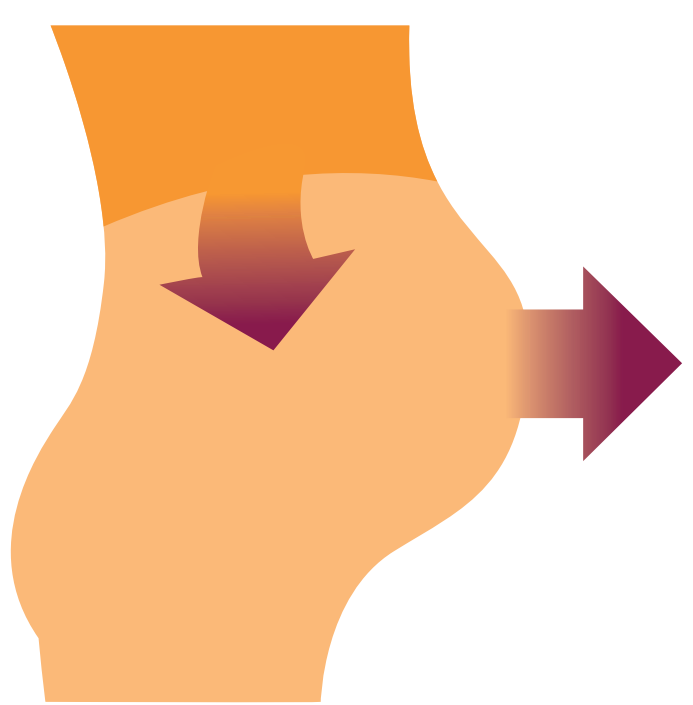

En mann i 50-årene var gjentatte ganger innlagt i sykehus med akutt innsettende bukdistensjon og spørsmål om ileus, men hadde hver gang normal avgang av luft og avføring. Røntgen oversikt abdomen var upåfallende. Det var normale funn ved blodprøver, øre og nedre endoskopi, røntgenundersøkelse av tynntarmen og CT- og MR-undersøkelse av abdomen. Petidin hadde frapperende effekt: Buken «klappet sammen» nærmest umiddelbart som en punktert ballong, men uten luftavgang.

For å belyse mekanismene nærmere ble pasienten undersøkt med elektromyografi av bukveggen og mellomgulvet under anfall (øverst til venstre) og etter langsom intravenøs administrasjon av $100 \mathrm{mg}$ petidin (nederst til venstre), selv om det var en utradisjonell indikasjon for denne undersøkelsen. Registreringene viste lav aktivitet $\mathrm{i}$ rectusmuskulaturen og høy aktivitet $\mathrm{i}$ diafragma under anfall og normalisering av denne forstyrrelsen etter petidintilførsel.

Samtidig kontraksjon av mellomgulvet og relaksasjon av bukveggen gir en «stem- peleffekt» som presser abdomen nedover og fremover (til høyre). Fenomenet vises tydelig på videoen. Årsaken er ukjent, men tilstanden er beskrevet i litteraturen (1). Pasienter med denne formen for funksjonell oppblåsthet har antakelig nytte av psykomotorisk fysioterapi - medikamentell behandling med sterke analgetika bør unngås (2).

\section{Jørgen Valeur}

jorgen.valeur@med.uib.no

Unger-Vetlesens institutt

Lovisenberg Diakonale Sykehus

\section{Trygve Hausken}

Institutt for indremedisin

Universitetet i Bergen

Pasienten har gitt samtykke til at artikkelen blir publisert.

Jørgen Valeur (f. 1979) er ph.d. og arbeider som assistentlege og forsker ved Klinikk for medisin og Unger-Vetlesens institutt.

Forfatter har fylt ut ICMJE-skjemaet og oppgir ingen interessekonflikter.
Trygve Hausken (f. 1951) er professor i gastroenterologi og overlege i fordøyelsessykdommer ved Haukeland universitetssykehus.

Forfatter har fylt ut ICMJE-skjemaet og oppgir ingen interessekonflikter.

\section{Litteratur}

1. Alvarez WC. Hysterical type of nongaseous abdominal bloating. Arch Intern Med (Chic) 1949; 84: $217-45$

2. Azpiroz F, Malagelada J-R. Abdominal bloating Gastroenterology 2005; 129: 1060-78.

Mottatt 31.5. 2012, første revisjon innsendt 17.6. 2012, godkjent 30.8. 2012. Medisinsk redaktør Merete Kile Holtermann.

Video på www.tidsskriftet.no 